\title{
An Insight into Ayurveda and Yogic Practices Sustain Physical and Mental Health in COVID-19 Pandemic
}

\author{
Devidas S. Bhagat ${ }^{1, *}{ }^{\mathbb{D}}$, Ranjitsingh K. Nimbalkar ${ }^{2} \mathbb{D}$, Sampada K. Shejul ${ }^{3(\mathbb{D})}$, \\ Wasudeo B. Gurnule ${ }^{4(\mathbb{D})}$, Aparna B. Gunjal ${ }^{5(\mathbb{D})}$, Gurvinder S. Bumbrah ${ }^{6}$ (D)
}

1 Department of Forensic Chemistry and Toxicology, Government Institute of Forensic Science, Aurangabad 431 004, (MS), India; devidas.bhagat@gov.in (D.D.B.);

2 Department of Forensic Biology, Government Institute of Forensic Science, Aurangabad 431 004, (MS), India; rknimbalkar@gmail.com (R.K.N.);

3 Department of Life Science, Vivekanand Arts, Sardar Dalipsingh Commerce and Science College, Aurangabad 431001 , (MS), India; sampadashejul@yahoo.com (S.K.S.);

4 Department of Chemistry, Kamla Nehru Mahavidyalaya, Nagpur-440024, (MS) India; wbgurnule@ gmail.com (W.B.G.);

5 Department of Microbiology, Dr. D.Y. Patil, Arts, Commerce \& Science College, Pimpri, Pune 411018, Maharashtra, India; aparnavsi@yahoo.com (A.B.G.);

6 Department of Chemistry, Biochemistry and Forensic Science, Amity School of Applied Sciences, Amity University, 122413, Haryana, India; bumbrah85@gmail.com (G.S.B.);

* Correspondence: devidas.bhagat@gov.in (D.S.B.);

Scopus Author ID 57201065245

Received: 26.03.2021; Revised: 28.04.2021; Accepted: 2.05.2021; Published: 9.05.2021

Abstract: The worldwide public health disaster caused due to a viral outbreak of the coronavirus disease 2019 (COVID-19 or SARS-CoV-2) challenges the entire healthcare system. The COVID-19 is a highly pathogenic viral transmittable infection that causes the severe acute respiratory syndrome. It is a kind of pneumonia virus and the third type of coronavirus after severe acute respiratory syndrome (SARS) and the Middle East respiratory syndrome (MERS). In December 2019, the third coronavirus was discovered in patients with infectious respiratory disease in the capital city Wuhan, Hubei province, and initiate a global pandemic. It has a very high human-to-human transmission ability, which results in spread rapidly all over the world. Today's necessary to understand the physiopathology of COVID19, which causes a global pandemic and infects more than 136 million people. The COVID-19 genome sequence is similar to the other two coronaviruses, with about $80 \%$ sequence identical with SARS-CoV and about $50 \%$ with MERS-CoV. Remarkably, COVID-19 has a 90\% similar whole-genome sequence with bat coronaviruses. The worldwide mortality rate of COVID-19 is 1 to $2 \%$. Ayurvedic remedies; yogic practices like yogasanas, breathing pranayama, and meditation; other traditional Indian practices include decoction and drinking of herbal remedies. The Ayurveda, Yogic science, and other ancient practices boost the immune system, improve lung function, improve physiological strengths, normalize cognitive functions, and reduce the pandemic's community speeding. Ayurvedic remedies and yogic practices help to cope up with the COVID-19 pandemic. Yoga and ayurvedic were elements of daily routine practices of peoples in ancient times to keep themselves healthy.

Keywords: COVID-19; Ayurveda; Yogic practices; pandemic; health; ancient Indian practices.

(C) 2021 by the authors. This article is an open-access article distributed under the terms and conditions of the Creative Commons Attribution (CC BY) license (https://creativecommons.org/licenses/by/4.0/).

\section{Introduction}

In December 2019, the global pandemic outbreak of SARS-CoV-2 in Wuhan, the capital city of Hubei province, spread dramatically into Wuhan city, with an ongoing risk of a global pandemic [1]. On $30^{\text {th }}$ January 2020, the World Health Organization (WHO) declared 
the public health emergency of international concern with the outbreak of SARS-CoV-2 and confirmed SARS-CoV-2 had a stronger transmission capacity related to an outbreak of SARS in 2003. On $11^{\text {th }}$ February 2020, the WHO officially named the disease caused by the nCoV2019 as a novel coronavirus disease COVID-19. The indexes of COVID-19 confirmed cases increased rapidly in the world [2]. The public mindset to obey strict lockdown, self-disciple quarantines could slow down community spread which correlates with how much people trust WHO, state and center governments health ministry advisory regarding health care [3]. SARS$\mathrm{CoV}-2$ belongs to the $\beta$-coronavirus family. COVID-19 is the third known zoonotic disease, after the severe acute respiratory syndrome (SARS-2003) and the Middle East Respiratory Syndrome (MERS-2012), both belonging to the $\beta$-coronavirus family [4]. It is a highly identical genome to bat coronavirus, pointing to bat as the natural host. Likewise, SARS-CoV-2 also uses the identical receptor, angiotensin-converting enzyme $2\left(\mathrm{ACE}_{2}\right)$ [5]. The COVID-19 pandemic type of global challenge transcends territorial, political, ideological, religious, cultural, and academic boundaries [6].

Yoga and ayurvedic were daily routine practices of people in ancient times to stay healthy. These traditional practices help to improve immunity, body physics, and mental stability. The coronavirus outbreak is not the first on the globe. There were many pandemic viral outbreaks reported in history. In ancient times, these practices helped to cope up with pandemic viral outbreaks. The worldwide pandemic crisis has affected every individual. The yogic practices and Ayurveda help a sustainable and holistic lifestyle enrichment in any pandemic situation. The relation between ancient Indian practices and human health illustrated in Figure 1.

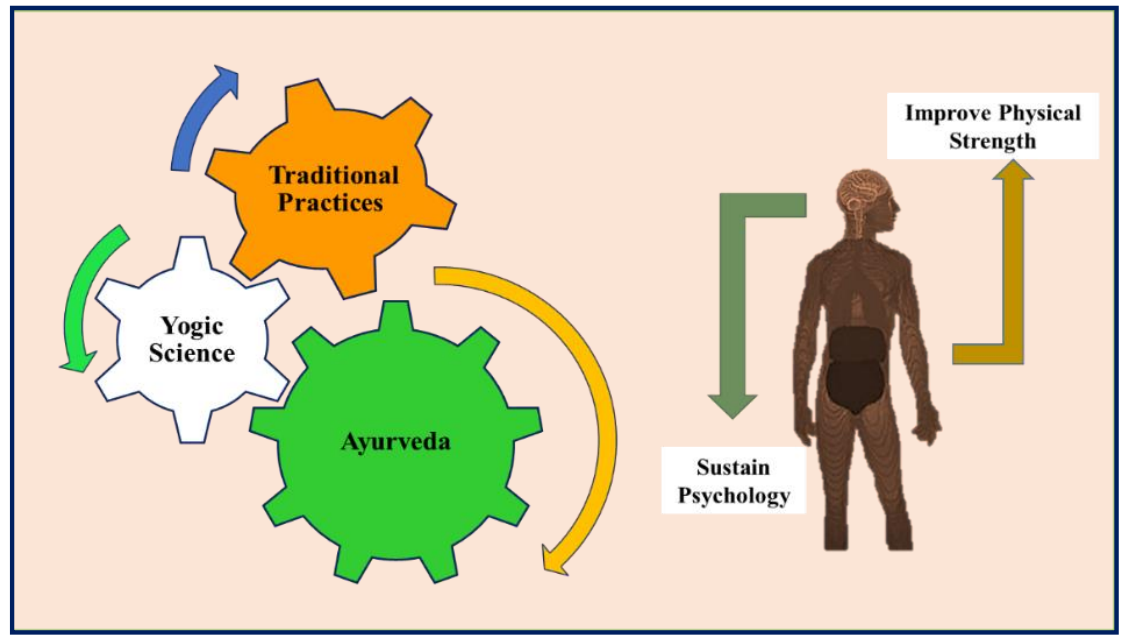

Figure 1. Ancient Indian practices and human health.

The present study's outline emphasizes all these practices with scientific reports and correlates their use for humankind to prevent themselves from pandemic viral outbreaks. The Yogic practices include yogasanas, breathing pranayama, a balanced diet, and meditation to help regain physiological and emotional stability. The ayurvedic herbal remedies help to improve the immunity of the system. The traditional routine practices decrease community spreading of this pandemic global outbreak like COVID-19. The review here focuses on scientific study and the use of ancient Indian methodologies to cope with the pandemic outbreak COVID-19 by balancing physical and mental health. 


\section{Yogic practices}

Yogic practice is a traditional Indian culture from ancient times and is considered the science of holistic living. The word yoga derived from the Sanskrit word 'Yuj' means 'to join' and indicates the consolidation of mind, body, and spirit. In today's era, the basic concept of yogic science and its influence on physiological function is ignored by the scientific community [7]. Yogic science deals with non-physical control centers' spiritual anatomy, called 'chakras', and attaining mastery over yogasanas influences particular glandular secretions. All these aspects help to control the mental and physiological function of the body [8]. The yogic practices (yogasanas, breathing pranayama, meditation, diet) might be optimized issues related to psychological and physiological health. The yogasanas, breathing pranayama, meditation, and a balanced diet are the elements of yogic practices.

\subsection{Yogasanas.}

According to a study of numerous ancient documents, there are 84 yoga poses acknowledged and granted by Lord Shiva. The broad spectrum of research demonstrating physiological benefits of various yogic practices (yogasanas) includes modification on blood pressure in prehypertensive case [9], improved mental and cognitive functioning, and lower levels of depressive symptoms, which is accompanied by an increase in telomerase activity suggesting improvement in stress-induced cellular aging [10], anti-aging, cognitive-behavioral practices [11], heart rate variability (HRV) [12], central nervous systems (CNS) [13] and cardiovascular [14]. The Yogic Science was part of an ancient lifestyle to achieve physical and spiritual harmony in life evolved in the Indian peninsula 5000 years ago [15]. The yogic practices include meditation, yogasanas, breathing pranayama, and a balance diet [16]. The therapies and diagnosis based on the pulse (Nadi) and analysis of Tridosha state (physical and emotional govern the function of our bodies on three fundamental energies level) of an individual suggest meditative yogic exercises to improve health issue [17].

\subsection{Meditation.}

Mindfulness meditation improves physical and emotional health, reported benefits to include flexibility in cognitive, affective, and social function [18], emotional intelligence (EI), perceived stress and negative mental health [19], anxiety [20], self-efficacy [21], improving school climate [22], improved cognition [23], alterations in the brain [24] and immune system [25]. The meditation practice helps maintain emotional stability and stress in the complete lockdown and home quarantine process.

\subsection{Pranayama Breathing.}

Yogic manuscripts define the 'Prana' is a dynamic strength that runs through distinct 'chakras' and 'nadis' in the system to retain the body healthy, stimulated, and rejuvenate. Pranayama Breathing plays an extremely pivotal role in the depiction and conservation of Prana. Yogic Pranayama breathing exercises are the practice of voluntary breath control in which the rhythm of inhalation (breathing in), retention (Kumbhaka or retention of the breath in the hatha yoga), and exhalation (breathing out) are consciously controlled [26]. The reported benefit of Pranayama breathing includes improving physical and mental fitness includes anxiety disorder in cardiovascular diseases patient [27], respiratory function [28], improvement 
in asthma patients [29], significantly reduces the indices of ventricular repolarization dispersion in patients with arrhythmia [30], a significant reduction in blood pressure [31] and boost immune function [32].

\subsection{Immunity boosting Indian food.}

It is one of the most important ways to stay healthy to strengthen immunity. Indian culture rich in biodiversity, having diverse food patterns. The great diversity in food patterns that are consumed daily makes Indian diets distinct from other countries. In routine Indian diets, cereals, millets, pulses, legumes, vegetables, fruits, and spices [33]. The traditional Indian food guidelines are prescribed in Ayurveda. The Indian diet has many similarities in Ayurvedic dietetics. It is also coined as Ayurvedic foods [34]. Ayurveda is a traditional system of medicines in India. Ayurveda illustrates how an individual can improve by establishing the connection between life elements, food, and body. Food is responsible for different aspects of an individual, including physical, temperamental, and mental states. To stay healthy, maintaining a stable, healthy diet routinely is essential [35]. The nutritional values of foods are enhanced by various traditional processing such as sprouting, malting, and fermentation [36].

Indian immunity-boosting balanced diet includes green leafy vegetables, apricots, berries, green peas, sprouts, yogurt, and honey. These food materials contain many immunityboosting nutrients like vitamins, water-soluble and insoluble fiber, flavonoids, protein, folate, potassium, iron, zinc, magnesium, calcium, carotenoids, which helps to boost and improve immunity.

\section{Ayurveda}

Traditionally, herbal-based medicines were used to treat many human diseases for thousands of years in India, Egypt, Greece, and the Middle East. The traditional Indian medical model is known as Ayurveda.

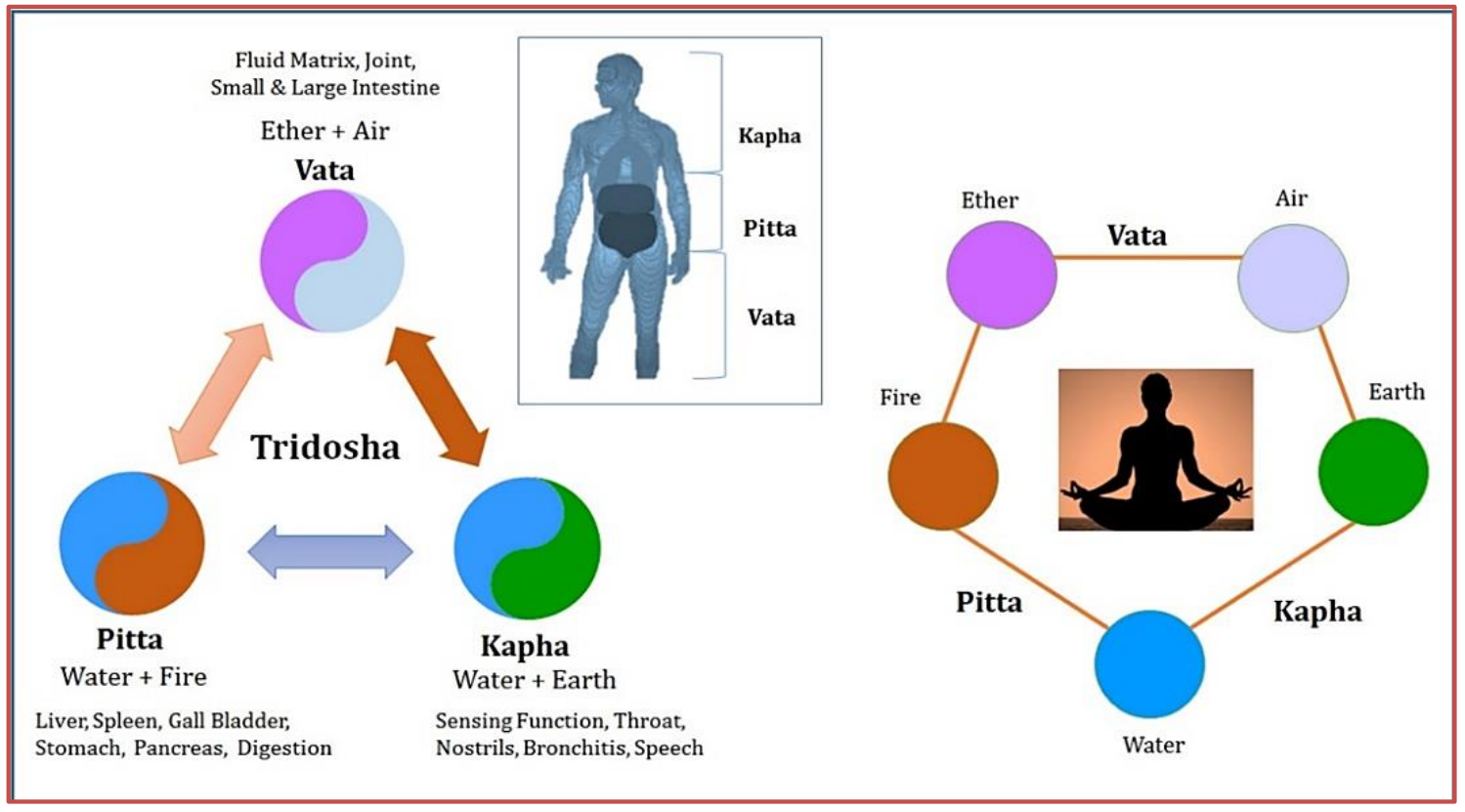

Figure 2. Tridosha, Prakriti and related diseases relation.

Ayurveda is one of the worldwide accepted oldest traditional medicine systems in India. The ancient wisdom in this traditional medicine system includes rich knowledge leading to new avenues in the herbal drug. Ayurveda has also allowed its vast documented knowledge of 
clinical practices, formulations, and medicinal plants [37]. Natural products from plants, animals, marine life, fungi, bacteria, and other organisms are important for modern drug discovery. The major classes of antibiotics like Penicillin's to Biaxin (Clarithromycin), Dificid (Fidoximycin), Zithromax (Azithromycin), and Erythromycin and classes of few antifungals drugs such as polyenes and echinocandins rely on natural product isolation from microbes and natural resources [38].

\subsection{Introduction to Tridosha and Prakriti (nature).}

Ayurveda trusts that the complete universe is composed of five elements: Vayu (Air), Jala (Water), Aakash (Space or ether), Prithvi (Earth), and Teja (Fire). These five elements (referred to as Pancha Mahabhoota in Ayurveda) are believed to form the human body's basic senses of humor in variable combinations. The diagnosis of disease in Ayurveda, the traditional medicine of India, is based on the concept of three major constitutional types Tridosha includes Vata, Pitta and Kapha defined as "Prakriti" and they control the basic physiological functions of the body, it is briefly illustrated in Figure 2 [39]. According to the World Health Organization (WHO) reports, herbal remedies are still used by up to 70-80\% of the world population [40]. Although the Indian Government lists 106 traditional medicines, mainly Ayurveda, Yoga, Unani, Siddha, and Homeopathy (AYUSH) are taught in selective universities [41]. The Ayurvedic insight, Charaka Samhita, described nine yonis (source of fermentation), viz. Phala (fruits), Dhanya (cereals), Mula (roots), Pushpa (flowers), Twak (bark), Sara (exudate), Kanda (branches), Patra (leaves), and Sharkara (sugar) for formulation and making of herbal medicine and Ashtanga Hridayam is primary ancient root texts of Ayurveda includes philosophy Ayurveda, the protocol of medicine and therapy and providing clear guidelines in all aspects of medicine and diagnosis of health [42].

\subsection{Immunity boosting herbal remedies.}

According to Ayurvedic science, the COVID-19 pandemic disease deals with Kapha, which is made up of water and earth. The Ayurvedic science helps to improve the immune system of the body, and controlling Kapha could be done by few herbal remedies includes drinking of turmeric (Curcuma longa) [43], Tulsi (Ocimum sanctum) [44], Garlic oil (Allium sativum) [45], Green tea (Camellia sinensis) [46], drumsticks (Moringa oleifera) and beans (Phaseolus vulgaris) [47], onion (Allium cepa) [48], ginger (Zingiber officinale) [49], Cumin (Cuminum cyminum) [50], Coriander (Coriandrum sativum L.) [51], Jeshthamadh or Liquorice (Glycyrrhiza glabra L.) [52], Heart-leaved moonseed or Gulvel (Tinospora cordifolia) [53], Amla (Phyllanthus emblica L) [54], Black pepper (Piper nigrum L.)[55], Majdalawieh and Elaichi (Elettaria cardamomum) [56]. The Prophylaxis and immunity-boosting active components/ingredients present in these medicinal plants are listed in Table 1.

Table 1. Immunity-boosting bioactive components present herbal remedies.

\begin{tabular}{c|l|l|l|l}
$\begin{array}{c}\text { Sr. } \\
\text { No. }\end{array}$ & \multicolumn{1}{|c|}{ Medicinal plants } & $\begin{array}{c}\text { Main Active } \\
\text { components }\end{array}$ & References \\
\hline 1 & Curcuma longa & Curcumin & Structure \\
\hline 2 & Ocimum sanctum & Eugenol &
\end{tabular}




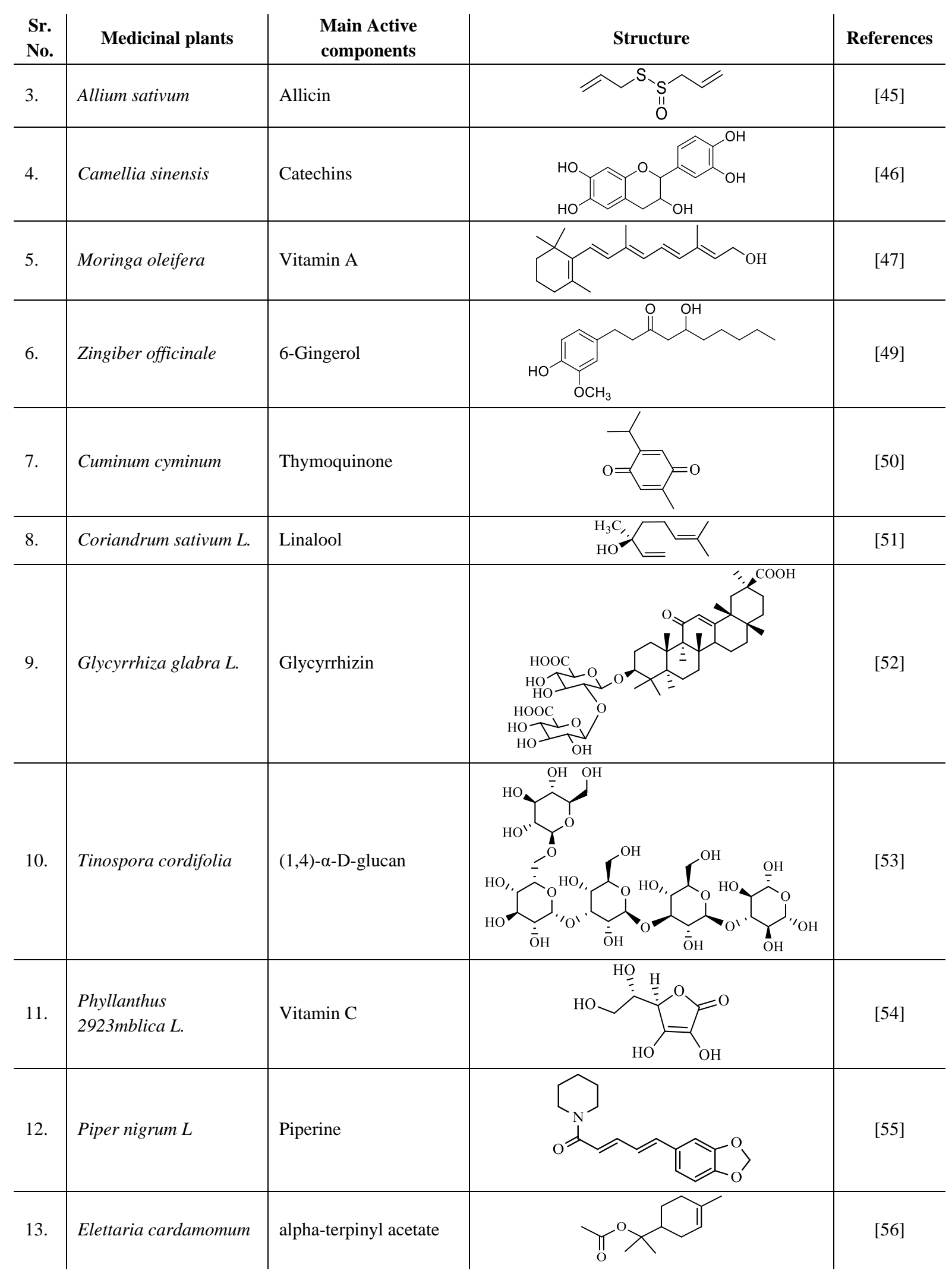

\subsection{Other immunity improving medicinal plants.}

The immune-boosting is an alternative remedy to cope up with any influenza. The ancient people used herbal remedies for improving and boosting the immune system. In the studies reported, immune-boosting Ayurvedic herbal remedies include Amandla impilo immune booster widely used South African herbal remedies [57], Avandula angustifolia [58], Moringa oleifera treatment increases Tibet expression in $\mathrm{CD}^{+} \mathrm{T}$ cells and remediates immune 
defects of malnutrition [59], Malva sylvestris [60], Mentha longifolia [61], Elephantopus scaber [62], Passiflora Incarnata [63], Xanthophyllomyces dendrorhous [63] and Cirrhina mrigala [65].

\subsection{Antiviral medicinal plant.}

In the history of humanity, many infectious diseases have been treated with herbals. Traditional medicine is increasingly solicited through the trade-practitioners and herbalists in the treatment of infectious diseases. Plant-based medicines exhibit potent antiviral activity, including medicine against herpes simplex virus type 1 (HSV-1) [66], ethanolic extract of Nilavembu Kudineer against dengue and chikungunya virus, anti-hepatotoxic, Cyperus rotundus against anti-hepatitis B virus, and hepatic CYP450 [67], Triphala is tri-fruits equal proportions (1:1:1) mixture of the dried fruits of Emblica officinalis, Terminalia belerica Linn and Terminalia chebula) in against treatment of Hepatitis A [68], Areca cutechu, Eugenia jambohnu, and Saruca indica extract against human immunodeficiency virus type 1 (HIV-1) protease [69], Strobilanthes cusia Leaf against Human Coronavirus NL63 [70], silymarin against EV-A71 [71], Isatidis Radix derived glucosinolate isomers against influenza A [72], and Polyalthia longifolia leaves extract against paramyxoviruses [73].

\subsection{Ayurveda can cure serious diseases.}

Diseases that may be cured by Ayurvedic medicine include allergic and inflammatory [74], Alzheimer's disease [75], cancer [76], cardiovascular disorders [77], malaria and dengue [78], ischemic stroke [79], diarrhea [80], tuberculosis [81] and cirrhosis [82].

\section{Traditional practices}

The ancient culture is a model of an integrated pattern of healthy life learned beliefs shared among the community, including thoughts, patterns of interaction, lifestyle, views, relation, practices, ethics, and values.

\subsection{Drinking of traditional beverages and decoction.}

Tea and coffee are generally consumed beverages throughout the globe, and they are rich sources of polyphenols. Polyphenols impart antioxidant property which is beneficial against diseases like cancer, cardiovascular diseases, and aging [83]. Medicinal plants are gradually explored in the food industry for their health-promoting benefits in herbal teas, such as Matricaria chamomilla (chamomile), Cymbopogon citratus (lemongrass) Aloe vera (aloe), Aspalathus linearis (rooibos) [84]. Beverages like tea, coffee, and decoction boost immunity, mood, and health.

\subsection{Say NAMASTE avoid handshake and hugging.}

Avoid handshakes and hugs. Simply say 'Namaste', which will help to maintain social distance and physical contact. Physical contact is a leading cause of the spread of the COVID19 viral outbreak. 


\subsection{Clean drinking and hot lemon water.}

Warm water helps in the muscles' process of contraction and relaxation and helps prepare the muscles for better movement. In the case of drinking water, touching of lips to the container (bottle) causes oral transmission of influenza to another person who comes in contact with the container. Drinking water slowly, sip by sip, helps avoid the spread of COVID-19 via usual drinking habit. Citrus fruit having many health benefits consist of various bioactive components viz., iso-limonene, citral, limonene, phenolic, flavanones, vitamin $\mathrm{C}$, and pectin [85].

\subsection{Common payers and funeral ceremonies are attained in Indian tradition.}

In Indian culture, the Hindus have small temples in the house for prayers of God. Generally, they involve the common prayers which protect them from the transmission and spreading harmful bacterial and viral disease. Also, in the Hindu tradition, those involved in attaining funeral ceremonies prioritize self-sanitization by taking a shower and washing clothes worn without touching anything in the house. These traditional methods control the spread of harmful influenza-like coronavirus.

\subsection{Removing footwear outside the house.}

Removing shoes before entering the home has advantages such as reducing dirt and dust in the home, lessening housework and cleaning, minimizing the introduction of diseases like COVID-19, and decreasing the transport of diseases from one place to another [86].

\subsection{Take spices in a routine diet.}

Spices take a significant place in the common person's routine due to their flavor, taste, and medicinal values. In the recent few decades, the major community focuses on using spices to treat many illnesses and health-benefit. The spices like cinnamon, ginger, fenugreek, cumin, black pepper, curry, mustard, anise, onion, and ginseng are potent biological activities used to cured many diseases [87]. Including few spices in the routine diet is beneficial to the immune system and health, as it strengthens us to fight against diseases like COVID-19.

Table 2. Summary of all practices to improve physical and mental health.

\begin{tabular}{|c|c|c|c|}
\hline Class & Protocol & Response & Reference \\
\hline Mediation & $\begin{array}{l}\text { Listening to relaxation music for } 12 \text { min per day for } \\
\text { 8-weeks }\end{array}$ & $\begin{array}{l}\text { Lower levels of depressive symptoms } \\
\text { and greater improvement in mental } \\
\text { health }\end{array}$ & {$[10]$} \\
\hline $\begin{array}{l}\text { Yogic } \\
\text { practices }\end{array}$ & $\begin{array}{l}\text { Yogasanas, breathing exercises, different cognitive } \\
\text { tasks }\end{array}$ & $\begin{array}{l}\text { Physiologically significant changes in } \\
\text { heart rate variability }\end{array}$ & {$[12]$} \\
\hline Yogasanas & $\begin{array}{l}\text { Advice yoga to patients with inactive ulcerative } \\
\text { colitis and impaired quality of life at weeks } 0,12 \text {, } \\
\text { and } 24 \text { intervals }\end{array}$ & $\begin{array}{l}\text { Lower the perceived stress and the } \\
\text { disease activity }\end{array}$ & {$[14]$} \\
\hline $\begin{array}{l}\text { Yogic } \\
\text { practices }\end{array}$ & $\begin{array}{l}\text { 8-week yoga program included two } 90-\text { min yoga } \\
\text { classes and five } 30 \text {-min home sessions per week }\end{array}$ & $\begin{array}{l}\text { Improved physical function, enhanced } \\
\text { mental or emotional state, enriched } \\
\text { sleep quality }\end{array}$ & {$[17]$} \\
\hline Mediation & $\begin{array}{l}20 \text { min regular daily practice of either concentrative, } \\
\text { mindfulness, or integrated meditation }\end{array}$ & 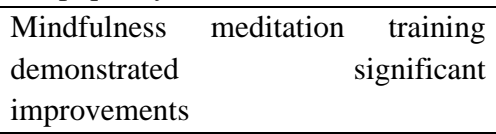 & {$[19]$} \\
\hline Meditation & Mindfulness meditation for weeks to months & $\begin{array}{l}\text { Emotional intelligence, general self- } \\
\text { efficacy, and perceived stress }\end{array}$ & {$[21]$} \\
\hline
\end{tabular}




\begin{tabular}{|c|c|c|c|}
\hline Class & Protocol & Response & Reference \\
\hline Meditation & $\begin{array}{l}\text { Meta-analysis of morphometric neuroimaging in } \\
\text { meditation practitioners }\end{array}$ & Meditation can alter brain structure & [24] \\
\hline Meditation & two and a half hours spend time in meditation & $\begin{array}{l}\text { Effects of meditation on how the brain } \\
\text { and immune systems respond and } \\
\text { stress }\end{array}$ & {$[25]$} \\
\hline Pranayama & $\begin{array}{l}\text { 15-minute yogic breathing exercises practiced } 5 \\
\text { times a week }\end{array}$ & $\begin{array}{l}\text { Significant systolic blood pressure } \\
\text { reduction in hypertension patient }\end{array}$ & {$[25]$} \\
\hline Pranayama & $\begin{array}{l}\text { Mild asthma practiced slow deep breathing for } 15 \\
\text { minutes twice a day for two consecutive } 2 \text {-week } \\
\text { periods }\end{array}$ & $\begin{array}{l}\text { control of breathing may contribute to } \\
\text { the control of asthma }\end{array}$ & [29] \\
\hline Pranayama & 15-minute daily pranayama Breathing & Reduction in blood pressure & [31] \\
\hline Pranayama & $\begin{array}{l}\text { Yoga practice was with an instructor for } 90 \text { minutes } \\
\text { once a week spread over } 12 \text { weeks daily at home for } \\
40 \text { minutes }\end{array}$ & $\begin{array}{l}\text { Improves antioxidant status, } \\
\text { immune function, and stress }\end{array}$ & {$[32]$} \\
\hline Diet & $\begin{array}{l}\text { The ideal combinations of traditional Indian diets } \\
\text { include cereals, millets, pulses, legumes, vegetables, } \\
\text { fruits, and spices }\end{array}$ & Health benefits & {$[33]$} \\
\hline $\begin{array}{l}\text { Herbal } \\
\text { remedy }\end{array}$ & The leaves of Tulsi or its extract & $\begin{array}{l}\text { Normalize the Kapha, Vata, fever, and } \\
\text { antiviral }\end{array}$ & [44] \\
\hline $\begin{array}{l}\text { Herbal } \\
\text { remedy }\end{array}$ & Garlic essential oil & $\begin{array}{l}\begin{array}{l}\text { Investigation into } \text { SARS-CoV-2 } \\
\text { resistance }\end{array} \\
\end{array}$ & {$[45]$} \\
\hline $\begin{array}{l}\text { Herbal } \\
\text { remedy }\end{array}$ & Golden milk of turmeric & Improve resistance power & {$[70]$} \\
\hline $\begin{array}{l}\text { Herbal } \\
\text { remedy }\end{array}$ & $\begin{array}{l}\text { Herbal desi-cava made-up of Tulsi, black pepper, } \\
\text { ginger, gulvel, jeshthamadh, green tea, Cardamom, } \\
\text { Asafoetida, Clove, and cinnamon }\end{array}$ & $\begin{array}{l}\text { Improve immunity, cognitive and } \\
\text { physiological functions }\end{array}$ & {$[83]$} \\
\hline Water & Hot lemon water contains vitamin $\mathrm{C}$ & Improve immunity and physiology & {$[84]$} \\
\hline Spices & Add spices in diet & Stimulate immunity & [87] \\
\hline
\end{tabular}

\section{Discussion}

This study retrieved the highlights of yogic and ayurvedic practices for balancing psychoneuroimmunology. The finding of ancient scientific information helps to understand ancient people's strategy to deal with an outbreak like COVID-19 with the help of yoga and Ayurveda practices. The yogic practices include yogasana, breathing pranayama, meditation, and a balanced diet to normalize psychological and physiological functions. The mindfulness meditation and breathing pranayama sustain mental and physical health, minimizing disorders like stress, anxiety, hypertension, and high blood pressure and immunity. Indian balanced diet boosts immunity due to the essential nutrients. The Ayurvedic practices are useful to improve the immunity of the system. The Ayurvedic remedies include golden milk of turmeric, decoction, desi-cava, tulsi leaves extract, and garlic extract. The traditional routine practices are useful to minimize the community spreading of the viral outbreak. Table 2 summarizes the applicability of yogic and Ayurvedic practices for the balancing of psychoneuroimmunology.

\section{Conclusions}

In the global pandemic of SARS-CoV-19, the general public suffers the issues related to cognitive and physiological health, including depression, anxiety, hypertension, stress, high blood pressure, weakening of body immunity, and cardiovascular functions. Review to understand how ancient people cope with an outbreak like COVID-19 with the help of yoga and Ayurveda. The symbolic suitability of ayurvedic remedies and yogic practices helps to boot immunity and regularize psychological function. The breathing pranayama improved the lungs' health (angiotensin-converting enzyme 2), reducing the threat of respiratory tract 
infections. The mindfulness meditation normalizes psycho-neuro-immunity in the pandemic outbreak. The traditional routine practices are useful to minimize the community spreading of the viral outbreak.

\section{Funding}

This review received no external funding.

\section{Acknowledgments}

This review has no acknowledgment.

\section{Conflicts of Interest}

The authors declare no conflict of interest.

\section{References}

1. Wang, H.; Wang, Z.; Dong, Y.; Chang, R.; Xu, C.; Yu, X.; Zhang, S.; Tsamlag, L.; Shang, M.; Huang, J.; Wang, Y.; Xu, G.; Shen, T.; Zhang, X.; Cai, Y. Phase-adjusted estimation of the number of Coronavirus Disease 2019 cases in Wuhan, China. Cell Discovery 2020, 6, 10, https://doi.org/10.1038/s41421-020-01480 .

2. Zheng, Y.-Y.; Ma, Y.-T.; Zhang, J.-Y.; Xie, X. COVID-19, and the cardiovascular system. Nature Reviews Cardiology 2020, 17, 259-260, https://doi.org/10.1038/s41569-020-0360-5.

3. Wu, J.T.; Leung, K.; Bushman, M.; Kishore, N.; Niehus, R.; de Salazar, P.M.; Cowling, B.J.; Lipsitch, M.; Leung, G.M. Estimating clinical severity of COVID-19 from the transmission dynamics in Wuhan, China. Nat. Med. 2020, 26, 506-510, https://doi.org/10.1038/s41591-020-0822-7.

4. Zimmermann, M.; Nkenke, E. Approaches to the management of patients in oral and maxillofacial surgery during COVID-19 pandemic. Journal of Cranio-Maxillofacial Surgery 2020, 48, 521-526, https://doi.org/10.1016/j.jcms.2020.03.011.

5. Chen, Y.; Liu, Q.; Guo, D. Emerging coronaviruses: Genome structure, replication, and pathogenesis. J. Med. Virol. 2020, 92, 418-423, https://doi.org/10.1002/jmv.25681.

6. Huang, H.; Fan, C.; Li, M.; Nie, H.-L.; Wang, F.-B.; Wang, H.; Wang, R.; Xia, J.; Zheng, X.; Zuo, X.; Huang, J. COVID-19: A Call for Physical Scientists and Engineers. ACS Nano 2020, 14, 3747-3754, https://doi.org/10.1021/acsnano.0c02618.

7. Celka, P.; Granqvist, N.; Schwabl, H.; Edwards, S.D. Development and evaluation of a cardiac coherence index for sleep analysis. Journal of Psychology in Africa 2020, 30, 44-52, https://doi.org/10.1080/14330237.2019.1689460.

8. Webb, J.B.; Rogers, C.B.; Thomas, E.V. Realizing Yoga's all-access pass: a social justice critique of westernized yoga and inclusive embodiment. Eating Disorders 2020, 28, 349-375, https://doi.org/10.1080/10640266.2020.1712636.

9. Mooventhan, A.; Nivethitha, L. Role of yoga in the prevention and management of various cardiovascular diseases and their risk factors: A comprehensive scientific evidence-based review. EXPLORE 2020, 16, 257263, https://doi.org/10.1016/j.explore.2020.02.007.

10. Lavretsky, H.; Epel, E.S.; Siddarth, P.; Nazarian, N.; Cyr, N.S.; Khalsa, D.S.; Lin, J.; Blackburn, E.; Irwin, M.R. A pilot study of yogic meditation for family dementia caregivers with depressive symptoms: effects on mental health, cognition, and telomerase activity. Int. J. Geriatr. Psychiatry 2013, 28, 57-65, https://doi.org/10.1002/gps.3790.

11. Miller, S.; Boxmeyer, C.; Romero, D.; Powell, N.; Jones, S.; Lochman, J. Theoretical Model of Mindful Coping Power: Optimizing a Cognitive Behavioral Program for High-Risk Children and Their Parents by Integrating Mindfulness. Clin. Child Fam. Psychol. Rev. 2020, 23, 393-406, https://doi.org/10.1007/s10567020-00312-6. 
12. Senthilnathan, S.; Patel, R.; Narayanan, M.; Katholil, G.; Janawadkar, M.P.R.; Radhakrishnan, T.S.; Sharma, K.K. An investigation on the influence of yogic methods on heart rate variability. Ann. Noninvasive Electrocardiol. 2019, 24, e12584, https://doi.org/10.1111/anec.12584.

13. Arambula, P.; Peper, E.; Kawakami, M.; Gibney, K.H. The Physiological Correlates of Kundalini Yoga Meditation: A Study of a Yoga Master. Appl. Psychophysiol. Biofeedback 2001, 26, 147-153, https://doi.org/10.1023/a:1011343307783.

14. Koch, A.K.; Schöls, M.; Langhorst, J.; Dobos, G.; Cramer, H. Perceived stress mediates the effect of yoga on quality of life and disease activity in ulcerative colitis. Secondary analysis of a randomized controlled trial. J. Psychosom. Res. 2020, 130, 109917, https://doi.org/10.1016/j.jpsychores.2019.109917.

15. Jayasinghe, S.R. Yoga in cardiac health (A Review). Eur. J. Cardiovasc. Prev. Rehabil. 2004, 11, 369-375, https://doi.org/10.1097/01.hjr.0000206329.26038.cc.

16. Kuntsevich, V.; Bushell, W.C.; Theise, N.D. Mechanisms of Yogic Practices in Health, Aging, and Disease. Mount Sinai Journal of Medicine: A Journal of Translational and Personalized Medicine 2010, 77, 559-569, https://doi.org/10.1002/msj.20214.

17. Alexander, G.K.; Innes, K.E.; Selfe, T.K.; Brown, C.J. "More than I expected": Perceived benefits of yoga practice among older adults at risk for cardiovascular disease. Complement. Ther. Med. 2013, 21, 14-28, https://doi.org/10.1016/j.ctim.2012.11.001.

18. Trautwein, F.-M.; Kanske, P.; Böckler, A.; Singer, T. Differential benefits of mental training types for attention, compassion, and theory of mind. Cognition 2020, 194, 104039, https://doi.org/10.1016/j.cognition.2019.104039.

19. Chu, L.-C. The benefits of meditation vis-à-vis emotional intelligence, perceived stress and negative mental health. Stress Health 2010, 26, 169-180, https://doi.org/10.1002/smi.1289.

20. Frances, S.; Shawyer, F.; Cayoun, B.; Enticott, J.; Meadows, G. Study protocol for a randomized control trial to investigate the effectiveness of an 8-week mindfulness-integrated cognitive behavior therapy (MiCBT) transdiagnostic group intervention for primary care patients. BMC Psychiatry 2020, 20, 7 , https://doi.org/10.1186/s12888-019-2411-1.

21. Charoensukmongkol, P. Benefits of Mindfulness Meditation on Emotional Intelligence, General SelfEfficacy, and Perceived Stress: Evidence from Thailand. Journal of Spirituality in Mental Health 2014, 16, 171-192, https://doi.org/10.1080/19349637.2014.925364.

22. Wisner, B.L. An Exploratory Study of Mindfulness Meditation for Alternative School Students: Perceived Benefits for Improving School Climate and Student Functioning. Mindfulness 2014, 5, 626-638, https://doi.org/10.1007/s12671-013-0215-9.

23. Zeidan, F.; Johnson, S.K.; Diamond, B.J.; David, Z.; Goolkasian, P. Mindfulness meditation improves cognition: Evidence of brief mental training. Conscious. Cogn. 2010, 19, 597-605, https://doi.org/10.1016/j.concog.2010.03.014.

24. Fox, K.C.R.; Nijeboer, S.; Dixon, M.L.; Floman, J.L.; Ellamil, M.; Rumak, S.P.; Sedlmeier, P.; Christoff, K. Is meditation associated with altered brain structure? A systematic review and meta-analysis of morphometric neuroimaging in meditation practitioners. Neurosci. Biobehav. Rev. 2014, 43, 48-73, https://doi.org/10.1016/j.neubiorev.2014.03.016.

25. Kabat-Zinn, J. A Study in Happiness-Meditation, the Brain, and the Immune System. Mindfulness 2018, 9 , 1664-1667, https://doi.org/10.1007/s12671-018-0991-3.

26. Misra, S.; Smith, J.; Wareg, N.; Hodges, K.; Gandhi, M.; McElroy, J.A. Take a deep breath: A randomized control trial of Pranayama breathing on uncontrolled hypertension. Advances in Integrative Medicine 2019, 6, 66-72, https://doi.org/10.1016/j.aimed.2018.08.002.

27. Chandrababu, R.; Kurup, S.B.; Ravishankar, N.; Ramesh, J. Effect of pranayama on anxiety and pain among patients undergoing cardiac surgery: A non-randomized controlled trial. Clinical Epidemiology and Global Health 2019, 7, 606-610, https://doi.org/10.1016/j.cegh.2019.01.009.

28. Lee, S.-H.; Carey, S.; Lazinski, M.; Kim, E.S. An integrative intervention program for college musicians and kinematics in cello playing. European Journal of Integrative Medicine 2019, 25, 34-40, https://doi.org/10.1016/j.eujim.2018.10.014.

29. Singh, V.; Wisniewski, A.; Britton, J.; Tattersfield, A. Effect of yoga breathing exercises (pranayama) on airway reactivity in subjects with asthma. The Lancet 1990, 335, 1381-1383, https://doi.org/10.1016/01406736(90)91254-8.

30. Dabhade, A.M.; Pawar, B.H.; Ghunage, M.S.; Ghunage, V.M. Effect of Pranayama (Breathing Exercise) on Arrhythmias in the Human Heart. EXPLORE 2012, 8, 12-15, https://doi.org/10.1016/j.explore.2011.10.004. 
31. McElroy, J.A.; Misra, S.; Vasile, M.; Hosokawa, M.C. Take a Deep Breath: A Pilot Study Demonstrating a Significant Reduction in Blood Pressure with 15 Minute Daily Pranayama Breathing. Ann. Behav. Sci. Med. Educ. 2012, 18, 15-18, https://doi.org/10.1007/BF03355200.

32. Lim, S.-A.; Cheong, K.-J. Regular Yoga Practice Improves Antioxidant Status, Immune Function, and Stress Hormone Releases in Young Healthy People: A Randomized, Double-Blind, Controlled Pilot Study. The Journal of Alternative and Complementary Medicine 2015, 21, 530-538, http://doi.org/10.1089/acm.2014.0044.

33. Platel, K. Chapter 7 - Functional foods in Indian tradition and their significance for health. In Nutritional and Health Aspects of Food in South Asian Countries, Prakash, J., Waisundara, V., Prakash, V., Eds. Academic Press: 2020, 87-98, https://doi.org/10.1016/B978-0-12-820011-7.00008-3.

34. Sarkar, P.; Lohith Kumar, D.H.; Dhumal, C.; Panigrahi, S.S.; Choudhary, R. Traditional and ayurvedic foods of Indian origin. Journal of Ethnic Foods 2015, 2, 97-109, https://doi.org/10.1016/j.jef.2015.08.003.

35. Ravishankar, B.; Shukla, V.J. Indian systems of medicine: a brief profile. African Journal of Traditional, $\begin{array}{lllll}\text { Complementary and } \quad \text { Alternative } & \text { Medicines } & \mathbf{2 0 0 7}, & 4, & \text { 319-37, }\end{array}$ https://www.ajol.info/index.php/ajtcam/article/view/31226.

36. Hotz, C.; Gibson, R.S. Traditional Food-Processing and Preparation Practices to Enhance the Bioavailability of Micronutrients in Plant-Based Diets. The Journal of Nutrition 2007, 137, 1097-1100, https://doi.org/10.1093/jn/137.4.1097.

37. Dias, D.A.; Urban, S.; Roessner, U. A Historical Overview of Natural Products in Drug Discovery. Metabolites 2012, 2, https://doi.org/10.3390/metabo2020303.

38. Chen, Y.; de Bruyn Kops, C.; Kirchmair, J. Data Resources for the Computer-Guided Discovery of Bioactive Natural Products. J. Chem. Inf. Model. 2017, 57, 2099-2111, https://doi.org/10.1021/acs.jcim.7b00341.

39. Govindaraj, P.; Nizamuddin, S.; Sharath, A.; Jyothi, V.; Rotti, H.; Raval, R.; Nayak, J.; Bhat, B.K.; Prasanna, B.V.; Shintre, P.; Sule, M.; Joshi, K.S.; Dedge, A.P.; Bharadwaj, R.; Gangadharan, G.G.; Nair, S.; Gopinath, P.M.; Patwardhan, B.; Kondaiah, P.; Satyamoorthy, K.; Valiathan, M.V.S.; Thangaraj, K. Genome-wide analysis correlates Ayurveda Prakriti. Sci. Rep. 2015, 5, 15786, https://doi.org/10.1038/srep15786.

40. Orona-Ortiz, A.; Medina-Torres, L.; Velázquez-Moyado, J.A.; Pineda-Peña, E.A.; Balderas-López, J.L.; Bernad-Bernad, M.J.; Tavares Carvalho, J.C.; Navarrete, A. Mucoadhesive effect of Curcuma longa extract and curcumin decreases the ranitidine effect, but not bismuth subsalicylate on ethanol-induced ulcer model. Sci. Rep. 2019, 9, 16622, https://doi.org/10.1038/s41598-019-53089-2.

41. Narahari, S.R.; Ryan, T.J.; Bose, K.S.; Prasanna, K.S.; Aggithaya, G.M. Integrating modern dermatology and Ayurveda in the treatment of vitiligo and lymphedema in India. Int. J. Dermatol. 2011, 50, 310-334, https://doi.org/10.1111/j.1365-4632.2010.04744.x.

42. Kendall, W.F.; Opara, E.C. Chapter 61 - Islet immunoisolation by microencapsulation. In Transplantation, Bioengineering, and Regeneration of the Endocrine Pancreas, Orlando, G., Piemonti, L., Ricordi, C., Stratta, R.J., Gruessner, R.W.G., Eds. Academic Press: 2020, https://doi.org/10.1016/B978-0-12-814833-4.00061-7.

43. Idowu-Adebayo, F.; Toohey, M. J.; Fogliano, V.; Linnemann, A. R., Enriching street-vended zobo (Hibiscus sabdariffa) drink with turmeric (Curcuma longa) to increase its health-supporting properties. Food Funct., 2021, 12, 761-770. https://doi.org/10.1039/D0FO02888F

44. Goothy, S.S.K.; Goothy, S.; Choudhary, A.; Potey, G.G.; Chakraborty, H.; Kumar, A.H.; Mahadik, V.K. Ayurveda's Holistic Lifestyle Approach for the Management of Coronavirus disease (COVID-19): Possible Role of Tulsi. International Journal of Research in Pharmaceutical Sciences 2020, 11, 16-18, https://doi.org/10.26452/ijrps.v11iSPL1.1976.

45. Thuy, B.T.P.; My, T.T.A.; Hai, N.T.T.; Hieu, L.T.; Hoa, T.T.; Thi Phuong Loan, H.; Triet, N.T.; Anh, T.T.V.; Quy, P.T.; Tat, P.V.; Hue, N.V.; Quang, D.T.; Trung, N.T.; Tung, V.T.; Huynh, L.K.; Nhung, N.T.A. Investigation into SARS-CoV-2 Resistance of Compounds in Garlic Essential Oil. ACS Omega 2020, 5, 83128320, https://doi.org/10.1021/acsomega.0c00772.

46. Wang, J.; Zhang, N.; Zhao, M.; Jing, T.; Jin, J.; Wu, B.; Wan, X.; Schwab, W.; Song, C. Carotenoid Cleavage Dioxygenase 4 Catalyzes the Formation of Carotenoid-Derived Volatile $\beta$-Ionone during Tea (Camellia sinensis) Withering. J. Agric. Food Chem. 2020, 68, 1684-1690, https://doi.org/10.1021/acs.jafc.9b07578.

47. Muni Swamy, G.; Ramesh, G.; Devi Prasad, R.; Meriga, B. Astragalin, (3-O-glucoside of kaempferol), isolated from Moringa oleifera leaves modulates leptin, adiponectin secretion and inhibits adipogenesis in 3T3-L1 adipocytes. Arch. Physiol. Biochem. 2020, 10.1080/13813455.2020.1740742, 1-7, https://doi.org/10.1080/13813455.2020.1740742. 
48. Kimoto-Nira, H.; Ohashi, Y.; Amamiya, M.; Moriya, N.; Ohmori, H.; Sekiyama, Y. Fermentation of onion (Allium cepa L.) peel by lactic acid bacteria for production of functional food. Journal of Food Measurement and Characterization 2020, 14, 142-149, https://doi.org/10.1007/s11694-019-00276-4.

49. Rahman, M.A.; Bulbul, M.R.H.; Kabir, Y. 13 - Plant-based products in cancer prevention and treatment. In Functional Foods in Cancer Prevention and Therapy, Kabir, Y., Ed. Academic Press: 2020, https://doi.org/10.1016/B978-0-12-816151-7.00013-2.

50. Koohsari, S.; Sheikholeslami, M.A.; Parvardeh, S.; Ghafghazi, S.; Samadi, S.; Poul, Y.K.; Pouriran, R.; Amiri, S. Antinociceptive and antineuropathic effects of cuminaldehyde, the major constituent of Cuminum cyminum seeds: Possible mechanisms of action. J. Ethnopharmacol. 2020, 255, 112786, https://doi.org/10.1016/j.jep.2020.112786.

51. Song, X.; Nie, F.; Chen, W.; Ma, X.; Gong, K.; Yang, Q.; Wang, J.; Li, N.; Sun, P.; Pei, Q.; Yu, T.; Hu, J.; Li, X.; Wu, T.; Feng, S.; Li, X.-Q.; Wang, X. Coriander Genomics Database: a genomic, transcriptomic, and metabolic database for coriander. Horticulture Research 2020, 7, 55, https://doi.org/10.1038/s41438-0200261-0.

52. Mitra Mazumder, P.; Pattnayak, S.; Parvani, H.; Sasmal, D.; Rathinavelusamy, P. Evaluation of immunomodulatory activity of Glycyrhiza glabra L roots in combination with zing. Asian Pacific Journal of Tropical Biomedicine 2012, 2, S15-S20, https://doi.org/10.1016/S2221-1691(12)60122-1.

53. Nair, P.K.R.; Melnick, S.J.; Ramachandran, R.; Escalon, E.; Ramachandran, C. Mechanism of macrophage activation by (1,4)- $\alpha$-d-glucan isolated from Tinospora cordifolia. Int. Immunopharmacol. 2006, 6, 18151824, https://doi.org/10.1016/j.intimp.2006.07.028.

54. Liu, X.; Zhao, M.; Wu, K.; Chai, X.; Yu, H.; Tao, Z.; Wang, J. Immunomodulatory and anticancer activities of phenolics from emblica fruit (Phyllanthus emblica L.). Food Chem. 2012, 131, 685-690, https://doi.org/10.1016/j.foodchem.2011.09.063.

55. Liu, S.; Luo, X.; Li, D.; Zhang, J.; Qiu, D.; Liu, W.; She, L.; Yang, Z. Tumor inhibition and improved immunity in mice treated with flavone from Cirsium japonicum DC. Int. Immunopharmacol. 2006, 6, 13871393, https://doi.org/10.1016/j.intimp.2006.02.002.

56. Majdalawieh, A.F.; Carr, R.I. In Vitro Investigation of the Potential Immunomodulatory and Anti-Cancer Activities of Black Pepper (Piper nigrum) and Cardamom (Elettaria cardamomum). J. Med. Food 2010, 13, 371-381, https://doi.org/10.1089/jmf.2009.1131.

57. Madikizela, B.; Ndhlala, A.R.; Rengasamy, K.R.R.; McGaw, L.J.; Van Staden, J. Pharmacological evaluation of two South African commercial herbal remedies and their plant constituents. S. Afr. J. Bot. 2017, 111, 291298, https://doi.org/10.1016/j.sajb.2017.03.038.

58. Yousefi, M.; Shabunin, S.V.; Vatnikov, Y.A.; Kulikov, E.V.; Adineh, H.; Khademi Hamidi, M.; Hoseini, S.M. Effects of lavender (Lavandula angustifolia) extract inclusion in diet on growth performance, innate immunity, immune-related gene expression, and stress response of common carp, Cyprinus carpio. Aquaculture 2020, 515, 734588, https://doi.org/10.1016/j.aquaculture.2019.734588.

59. Pilotos, J.; Ibrahim, K.A.; Mowa, C.N.; Opata, M.M. Moringa oleifera treatment increases Tbet expression in CD4+ T cells and remediates immune defects of malnutrition in Plasmodium chabaudi-infected mice. Malar. J. 2020, 19, 62, https://doi.org/10.1186/s12936-020-3129-8.

60. Rashidian, G.; Kajbaf, K.; Prokić, M.D.; Faggio, C. Extract of common mallow (Malvae sylvestris) enhances growth, immunity, and resistance of rainbow trout (Oncorhynchus mykiss) fingerlings against Yersinia ruckeri infection. Fish Shellfish Immunol. 2020, 96, 254-261, https://doi.org/10.1016/j.fsi.2019.12.018.

61. Heydari, M.; Firouzbakhsh, F.; Paknejad, H. Effects of Mentha longifolia extract on some blood and immune parameters, and disease resistance against yersiniosis in rainbow trout. Aquaculture 2020, 515, 734586, https://doi.org/10.1016/j.aquaculture.2019.734586.

62. Doan, H.V.; Hoseinifar, S.H.; Sringarm, K.; Jaturasitha, S.; Khamlor, T.; Dawood, M.A.O.; Esteban, M.Á.; Soltani, M.; Musthafa, M.S. Effects of elephant's foot (Elephantopus scaber) extract on growth performance, immune response, and disease resistance of nile tilapia (Oreochromis niloticus) fingerlings. Fish Shellfish Immunol. 2019, 93, 328-335, https://doi.org/10.1016/j.fsi.2019.07.061.

63. Pastorelli, G.; Faustini, M.; Luzi, F.; Redaelli, V.; Turin, L. Passiflora Incarnata powder extract in postweaning piglets feeding slightly improves wellbeing and immune parameters. Livestock Science 2020, 235, 104000, https://doi.org/10.1016/j.livsci.2020.104000.

64. de la Fuente, J.L.; Rodríguez-Sáiz, M.; Schleissner, C.; Díez, B.; Peiro, E.; Barredo, J.L. High-titer production of astaxanthin by the semi-industrial fermentation of Xanthophyllomyces dendrorhous. J. Biotechnol. 2010, 148, 144-146, https://doi.org/10.1016/j.jbiotec.2010.05.004. 
65. Harikrishnan, R.; Balasundaram, C.; Dharaneedharan, S.; Moon, Y.-G.; Kim, M.-C.; Kim, J.-S.; Heo, M.-S. Effect of plant active compounds on immune response and disease resistance in Cirrhina mrigala infected with fungal fish pathogen, Aphanomyces invadans. Aquacult. Res. 2009, 40, 1170-1181, https://doi.org/10.1111/j.1365-2109.2009.02213.x.

66. Alché, L.E.; Berra, A.; Veloso, M.J.; Coto, C.E. Treatment with meliacine, a plant derived antiviral, prevents the development of herpetic stromal keratitis in mice. J. Med. Virol. 2000, 61, 474-480, https://doi.org/10.1002/1096-9071(200008)61:4<474::AID-JMV10>3.0.CO;2-K.

67. Jain, J.; Kumar, A.; Narayanan, V.; Ramaswamy, R.S.; Sathiyarajeswaran, P.; Shree Devi, M.S.; Kannan, M.; Sunil, S. Antiviral activity of ethanolic extract of Nilavembu Kudineer against dengue and chikungunya virus through in vitro evaluation. J. Ayurveda Integr. Med. 2020, 11, 329-335, https://doi.org/10.1016/j.jaim.2018.05.006.

68. Chandrakumar, A.; Xavier, A.; Xavier, A.; Manakkadiyil, A.; Reghu, A.; Thomas, L. Implications of traditional medicine in the treatment of Hepatitis A in Kerala. Journal of Traditional and Complementary Medicine 2016, 6, 316-320, https://doi.org/10.1016/j.jtcme.2016.01.004.

69. Kusumoto, I.T.; Nakabayashi, T.; Kida, H.; Miyashiro, H.; Hattori, M.; Namba, T.; Shimotohno, K. Screening of various plant extracts used in ayurvedic medicine for inhibitory effects on human immunodeficiency virus type 1 (HIV-1) protease. Phytother. Res. 1995, 9, 180-184, https://doi.org/10.1002/ptr.2650090305.

70. Tsai, Y.-C.; Lee, C.-L.; Yen, H.-R.; Chang, Y.-S.; Lin, Y.-P.; Huang, S.-H.; Lin, C.-W. Antiviral Action of Tryptanthrin Isolated from Strobilanthes cusia Leaf against Human Coronavirus NL63. Biomolecules 2020, 10, https://doi.org/10.3390/biom10030366.

71. Lalani, S.S.; Anasir, M.I.; Poh, C.L. Antiviral activity of silymarin in comparison with baicalein against EVA71. BMC Complementary Medicine and Therapies 2020, 20, 97, https://doi.org/10.1186/s12906-020-28802.

72. Nie, L.-X.; Wu, Y.-1.; Dai, Z.; Ma, S.-c. Antiviral activity of Isatidis Radix derived glucosinolate isomers and their breakdown products against influenza $\mathrm{A}$ in vitro/ovo and mechanism of action. J. Ethnopharmacol. 2020, 251, 112550, https://doi.org/10.1016/j.jep.2020.112550.

73. Yadav, P.; Choudhury, S.; Barua, S.; Khandelwal, N.; Kumar, N.; Shukla, A.; Garg, S.K. Polyalthia longifolia leaves methanolic extract targets entry and budding of viruses-an in vitro experimental study against paramyxoviruses. J. Ethnopharmacol. 2020, 248, 112279, https://doi.org/10.1016/j.jep.2019.112279.

74. Talmale, S.; Bhujade, A.; Patil, M. Anti-allergic and anti-inflammatory properties of Zizyphus mauritiana root bark. Food Funct. 2015, 6, 2975-2983, https://doi.org/10.1039/C5FO00270B.

75. Bhattacharjee, A.; Chakraborty, R.; Sen, S. Scientific Basis for Ayurvedic Medicinal Plants Against Alzheimer's Disease. In Herbal Medicine in India, Springer: 2020; 51-67, https://doi.org/10.1007/978-98113-7248-3_5.

76. Borah, P.; Banik, B.K. 22 - Medicinal plants and their compounds with anticancer properties. In Green Approaches in Medicinal Chemistry for Sustainable Drug Design, Banik, B.K., Ed. Elsevier: 2020, https://doi.org/10.1016/B978-0-12-817592-7.00023-X.

77. Maulik, S.K.; Talwar, K.K. Therapeutic Potential of Terminalia Arjuna in Cardiovascular Disorders. Am. J. Cardiovasc. Drugs 2012, 12, 157-163, https://doi.org/10.2165/11598990-000000000-00000.

78. Govindarajan, M.; Rajeswary, M.; Hoti, S.L.; Bhattacharyya, A.; Benelli, G. Eugenol, $\alpha$-pinene and $\beta$ caryophyllene from Plectranthus barbatus essential oil as eco-friendly larvicides against malaria, dengue and Japanese encephalitis mosquito vectors. Parasitol. Res. 2016, 115, 807-815, https://doi.org/10.1007/s00436015-4809-0.

79. Jhelum, P.; Wahul, A.B.; Kamle, A.; Kumawat, S.; Kumar, A.; Bhutani, K.K.; Tripathi, S.M.; Chakravarty, S. Sameerpannag Ras Mixture (SRM) improved neurobehavioral deficits following acute ischemic stroke by attenuating neuroinflammatory response. J. Ethnopharmacol. 2017, 197, 147-156, https://doi.org/10.1016/j.jep.2016.07.059.

80. Sharma, D.K.; Gupta, V.K.; Mondal, D.B. Evaluation of protective effect of aqueous extract of Phyllanthus emblica fruit on duodenum mucosa in experimentally induced diarrhea in albino Wistar rats. Comp. Clin. Path. 2019, 28, 297-303, https://doi.org/10.1007/s00580-018-2830-2.

81. Mangwani, N.; Singh, P.K.; Kumar, V. Medicinal plants: Adjunct treatment to tuberculosis chemotherapy to prevent hepatic damage. J. Ayurveda Integr. Med. 2020, 11, 522-528, https://doi.org/10.1016/j.jaim.2019.02.004. 
82. Philips, C.A.; Paramaguru, R.; Augustine, P.; Rajesh, S.; Ahamed, R.; George, T.; Padsalgi, G. A SingleCenter Experience on Outcomes of Complementary and Alternative Medicine Use Among Patients With Cirrhosis. Hepatology Communications 2019, 3, 1001-1012, https://doi.org/10.1002/hep4.1355.

83. Bandyopadhyay, P.; Ghosh, A.K.; Ghosh, C. Recent developments on polyphenol-protein interactions: effects on tea and coffee taste, antioxidant properties and the digestive system. Food Funct. 2012, 3, 592605, https://doi.org/10.1039/C2FO00006G.

84. Pereira, C.G.; Barreira, L.; Bijttebier, S.; Pieters, L.; Marques, C.; Santos, T.F.; Rodrigues, M.J.; Varela, J.; Custódio, L. Health promoting potential of herbal teas and tinctures from Artemisia campestris subsp. maritima: from traditional remedies to prospective products. Sci. Rep. 2018, 8, 4689, https://doi.org/10.1038/s41598-018-23038-6.

85. Chhikara, N.; Kour, R.; Jaglan, S.; Gupta, P.; Gat, Y.; Panghal, A. Citrus medica: nutritional, phytochemical composition and health benefits - a review. Food Funct. 2018, 9, 1978-1992, https://doi.org/10.1039/C7FO02035J.

86. Hunter, C. M.; Williamson, D.H. Z.; Pearson, M.; Saikawa, E.; Gribble, M. O.; Kegler M.; Safe community gardening practices: focus groups with garden leaders in Atlanta, Georgia, Local Environment, 2020, 25, 1835, https://doi.org/10.1080/13549839.2019.1688268

87. Sanlier, N.; Gencer, F. Role of spices in the treatment of diabetes mellitus: A minireview. Trends Food Sci. Technol. 2020, 99, 441-449, https://doi.org/10.1016/j.tifs.2020.03.018. 